\title{
Comparative Analysis of the Autoregressive Equation that Describe the Generating Information Process of Inflation in Regards of a Methodological Change of Puerto Rico's Consumer Price Index (CPI)
}

\author{
By Carlos A. Rodriguez*
}

This paper analyzes the variation in the autoregressive $(A R)$ structure of inflation due to a methodological change in the consumer price index (CPI) of Puerto Rico. The literature suggests that the inflation had been significantly affected by the demand and supply forces, the monetary policy of the USA and by the different transformations of the Puerto Rican economy. This means that any change in its dynamics, due to methodological aspects, should be analyzed deeply. If not there will be serious implications for decision making and policy, because the study of this variable can be based on wrong premises and commit specification errors. A time series methodological analysis was performed using statistical analysis, lag length criteria, correlogram, unit root and structural tests. The purpose of this methodology is to develop the generating information process that provides the dynamic structure of the series of the inflation with the 1984 and 2006 bases. According to the results the series of inflation, with the new methodology, shows a more stable behavior than the old one, but it is close to have a unit root process.

Keywords: CPI Methodology, Inflation Rate, Macroeconomic Policy, Time Series Analysis.

\section{Introduction}

In 2009 the Department of Labor and Human Resources of Puerto Rico developed a new consumer price index (CPI). Among the main changes are included: the review of the basket of goods and services in the CPI, the change in the base year 2006, the elimination of the extreme values of the collected prices, the incorporation of two methodologies for imputing prices (methodology of the arithmetic mean to determine the missing values of unquoted items and the simple imputation in the rent category), and the replacement of the arithmetic mean which was used to estimate the relative prices of the categories in the first aggregation step, by the geometric mean and calculation of CPI monthly from 2006 to the most recent application of the readjusted expense.

All these measures helped eliminate the overestimation observed in the CPI and therefore the inflation rate (Department of Labor and Human Resources 2010).

After this methodological change, the research in Puerto Rico related to the dynamic of the inflation rate and economic and econometric relevance is practically null. However, this kind of research took more importance due to the direct effect of the economic performance of the island and the external factors

\footnotetext{
${ }^{*}$ Professor of Economics, University of Puerto Rico, Puerto Rico.
} 
(especially in the last ten years) over the price system. After the derogation of the Section 936 (which used to give some benefits to the foreign firms, like tax exemption and political stability), ${ }^{1}$ the recession of the USA economy, the government debt, the bond market instability and the fluctuation of some of the principal economic variables (like employment and economic activity), it is fundamental to study the variability in the dynamic process of inflation.

Also, there will be serious implications for decision making and policy if what happened, with the stationary and the existence of one or more unit roots in prices and inflation, is not analyzed. That is to say, it can be based on wrong premises. For instance, someone can point out the past is more important than the present or that the present and past are equally important in the future evolution of the series. This can lead to specification errors, efficiency loss and invalidation when building macro-econometric models (Rodriguez 2004).

This paper attempts to contribute to this discussion by analyzing the generating information process of inflation. The dynamic series of inflation built with the 1984 base year, will be compared to the new methodology, which has a 2006 base year. The Statistical analysis together with the lag length criteria, correlogram, unit root and structural breaks tests will be used to develop the equation that describes the process of information of the inflation. This is an autoregressive (AR) equation that describes the changes in the dynamic structure of the series. These changes in the dynamic structure of the series will give the information for comparing the dynamic changes in the inflation. Inflation occurs through change in the CPI in the month for the year " $t$ " compared with the same month in the year " $t-1 "$.

The next section presents a historical analysis of inflation in the Puerto Rican economy. Further, a detailed analysis is performed on the stationarity and the existence of one or more unit roots in the studied series. At last, the most relevant conclusions of this paper are presented.

\section{The History of Inflation in Puerto Rico}

Inflation is a global problem that occurs worldwide in every country. According to the history of inflation, in Latin America, during the 70s and 80s, many countries adopted the control of inflation as the primary objective of its monetary politics. However, fiscal policy and any other economic policy need to contribute to comply with the proposed inflation target.

In these countries, high levels of inflation had a negative effect on the investment and distorted the tradeoff between consumption and savings

\footnotetext{
${ }^{1}$ The Section 936 of the Internal Revenue Code of the United States was created to encourage the US to invest in Puerto Rico by providing exemption for federal taxes with the same political stability with the US. This section was derogated in 1996. The main reason was the tax evasion from the companies that were subject to this section. These companies report that all of their gains were generated on the Island and thus did not pay taxes in the United States. However, after the derogation, these companies had 10 years enjoying these benefits. Since 2006, these benefits have expired and many of these companies moved their facilities abroad. Until today it has not arisen any proposal that would replace section 936.
} 
(Rodriguez 2004). Nevertheless, the case of Puerto Rico is special, because it does not consider inflation in their economic policy agenda (Rodriguez 2004). The main reason lays in the relationship of the economy of the island to the USA. From 1898 Puerto Rico is an unincorporated territory of the USA and became a commonwealth of the USA in 1952. The negotiation of the commonwealth status culminated in a Puerto Rican constitution that would specify the areas of intervention between the federal government of the USA and that of the territorial government of Puerto Rico. Although, the constitution of Puerto Rico did not really change the fundamental relationship between the two governments, the new status was nevertheless beneficial to the dominant political party (Partido Popular Democrático), as well as to Washington, as it seemed to address the USA as mandate for decolonization (Villamil 1976). Coincidentally, the political settlement of commonwealth status accompanied the emergence of the USA as the most dominant country of the world. The island quickly became a logical choice for USA hegemony in both political and economic terms in the wake of the Second World War and the onset of the Cold War, with all its concomitant military expenditures.

Given the geopolitics of the day, Washington gave priority to resolving the long-standing problems in Puerto Rico through an economic strategy of development, investment and export. In exchange, the Puerto Rican government would show flexibility and abandon its previous reform program. For example, in 1947, the First Law of Industry Incentives (Ley de Incentivos Industriales) was approved which gave a tax holiday on profits for foreign companies working on the island. The following year, in a show of liberalization, the government of Puerto Rico would sell the factories it had recently sponsored under the program of Fomento. ${ }^{2}$ The objective of both moves was to attract a variety of industries to the island and the model of development became known as "Operation Bootstrap". Through the fiscal incentives of "Operation Bootstrap", the island began industrializing and fundamental transformations took place in the productive processes of the island economy. During the initial phase (1947-1956), laborintensive light manufacturing was attracted, consisting primarily of textiles which consumed little energy and generated low levels of pollution (Commerce Department 1979, Dietz 1989, Villamil 1976). However, textiles are a quintessentially competitive industry and generated only low levels of profit. The comparative advantage in textiles shifted quickly in the wake of the Kennedy Round of the General Agreement on the Tariffs and Trade (GATT) negotiation, which lowered tariffs on labor-intensive manufacture from the Far East. In other words, any efficiency advantage of the island in the production of textiles did not compensate for the differential salaries between Puerto Rico and Hong Kong. This deteriorating comparative advantage was accentuated by the implementation of the USA federal minimum wage of the island. One can even say that, during this period, inflation was driven by compliance with the mandated USA minimum wage floor.

\footnotetext{
${ }^{2}$ A national and international boycott of the government financed factories (Fomento) also precipitated their closure. Nevertheless, the closure may also be attributed to the difficulties in establishing distribution channels with the larger market (Lewis 1949).
} 
The second stage of industrialization (1956-1973) witnessed the construction of refineries and a large-scale of the petrochemical industry both, driven by a federal quota system that apportioned importations of petroleum distinct states. The absolute and relative role of labor was diminished with respect to capital during this second phase. ${ }^{3}$ Inasmuch both refineries and petrochemicals are highly energy-intensive, both would also be highly polluting (Commerce Department 1979, Dietz 1989, Villamil 1976). Therefore, the subsidy was both fiscal and environmental. The hope of the island government was the development of oilrefining capacity that would generate supplies of intermediary products for the local industry, while also reducing the energy dependence of the island. For example, an ample supply of relatively low cost electric power would facilitate energy-intensive industries like aluminum, broadening the raw material base of Puerto Rico. However, this did not happen. Industry tended to prefer proximity to its markets rather than proximity to its inputs (Villamil 1976).

One can argue that "Operation Bootstrap" made Puerto Rico a little more than a "manufacturing enclave" within the USA. The sole advantage for Puerto Rico seemed to be the employment that would be generated from the final assembly; the disadvantages appeared manifold. The latter began with the fact that most businesses were administered from the USA, employing almost no local management, likewise, the lion's share of inputs came from the mainland. Local light industries would now have to compete directly with those from the mainland whose variable costs were far lower. For these industries, factory prices had increased, thereby aggravating already extant structural problems. The tourism sector was also not exempt from these cost increases, which were compounded by high transportation costs. To make matters worse the government did not undertake an adequate promotional campaign to promote the island on the mainland.

Generalized factor price increases were exaggerated in food markets due to quasi-monopolistic conditions and in 1974, the Planning Board of Puerto Rico was formally called for the expansion of the antitrust section of the Justice Department and for a clear policy that would deploy the import and distribution corporation to encourage competition. The fact that nothing happened is evidence of the political strength underpinning the structural problems on the island. For the most vulnerable segments of the population, faced with high price levels and low levels of employment, migration to the mainland became the relief valve (Perloff 1952). Nevertheless, migration and the subsequent remittances did not resolve the economic instability generated by inflation and unemployment.

By the mid-60's, measures were being proposed to address the structural problems of integration with the federal system. Among the proposals were certain job classifications being exempt from the USA minimum wage, the reduction of legal holidays and a moratorium on new fringe benefits. Restrictions on foreign investment were also discussed in the context of the possibility that the majority of the Puerto Rican government bonds might end up in the hands of foreign investors

\footnotetext{
${ }^{3}$ The mean of gross internal investment in fixed capital went from a minimum value of 73.9 million dollars in 1947 to a maximum value of 973.5 in 1972.
} 
aggravating the political dependency of the economy and leading to the real possibility of capital flight, with all the attendant negative impacts for public finance. Such arguments were generally ignored.

Thirty years ago, the strategy of economic development had been based on attracting foreign capital via tax holidays, de jure or de facto subsidies (infrastructure or environment) and relatively low salary scales (Quinones 1994). The year 1976 may be considered a watershed in the economic development of Puerto Rico. However, Section 936 of the Federal Tax Code ${ }^{4}$ of 1976 took effect and granted a credit for income generated from assets and liabilities originating in Puerto Rico as well as for taxes paid on foreign income. A deduction would also apply to dividends remitted to the parent company (Planning Board 1994, Ruiz and Zalacain 1996). Most of the multinational companies who responded to these fiscal incentives hailed from the USA.

In particular, Section 936 was created to attract foreign investment in Puerto Rico and offset some of the negative impacts of compliance with other federal laws, viz. the minimum wage and the Jones Act. ${ }^{5}$ There is little doubt the incentive package enabled the development of a high technology sector on the island which would become one of the most dynamic sectors ${ }^{6}$ (Quinones 1994).

Businesses operating under Section 936 generated, both directly and indirectly, a large number of jobs and investment. The new activity also contributed to the tax coffers of the island through taxes on the repatriation of profits, income and patents. Nevertheless, the President Bill Clinton overturned Section 936 on August 20, 1996 and a transition period was established for the phasing out of the incentives. During this period, the government needs to seek new stimuli for industrial development. However, the flaw in such reasoning is the assumption that Puerto Rico enjoys instrumental complementarily indeed; the only significant attraction of capital to the island seems to have been the tax incentives (Catala 1993).

Nowadays, the nature of the problem of economic development in Puerto Rico is not really distinct from what it was forty years ago. None of the measures, inspired by the various development models has fundamentally resolved structural problems of development. One sees persistent economic instability as well as a recent decline in the real gross domestic product (GDP), a high level of unemployment and a downward cycle of fixed capital

\footnotetext{
${ }^{4}$ The antecedents to Section 936 originate in 1921 with Section 262. Section 262 of the Federal Income Tax Code was designed for USA companies established in the Philippine islands, then a possession of the USA. The requirements to qualify for exemption under the Section were: at least $80 \%$ of the income would originate from commercial activities in the possession and $50 \%$ or more from incomes that originated in company operations in the possession (the condition 80-50). In 1955, this law was incorporated into the Federal Income Tax Code as Section 931, which continued offering a full exemption to incomes generated from USA corporations in Puerto Rico, American Samoa, Guam and the Panama Canal.

${ }^{5}$ The Act requires island-mainland ship transportation to fly under the American flag (one of the most expensive in the world), imposes USA citizenship on Puerto Ricans and reserves to the USA all powers correspondent to customs, immigration, mail services, maritime law, defense, commerce and all matters relating to sovereignty.

${ }^{6}$ More than $60 \%$ of the 936 firms are in clothing, pharmaceuticals, machinery, scientific and professional instrumentation (Catala 1993).
} 
investment accompanied by inflation rates higher than those on the mainland. Nevertheless, the standard of living of Puerto Ricans does not seem to have borne the full brunt of this instability, cushioned by federal transfers and public and private debt that, in turn, translate into inflationary pressures from the demand side. It means that, on the aggregate demand side, growth in private consumption, especially in imported goods and federal transfers have been key factors in terms of the increase of the local economy and the wellbeing of the people in the Island. Likewise, they have promoted no effective long-run policies to encourage savings and therefore accumulate capital.

Moreover, there are no local monetary policy measures to try to accommodate the shocks affecting economic activity. The USA monetary policy has a direct effect on the local economy. Also, the currency used on the island is the dollar. Upon arrival of the Americans in 1898, the dollar starts to be used as the currency allowing the free flow of capital, labor, goods and services between the two economies (Tobin 1976, Rodriguez 2003, Rodriguez 2004, Rodríguez 2008). From these actions there are two results: a) Puerto Rico has no ability to monetize its debts and b) its stock of money depends on the monetary policy of the USA (Rodriguez 2005). In monetary terms, Puerto Rico maintains a link directly with the Federal Reserve Bank. It appears as part of the second district of New York. Estrella (2005) notes that in some dispositions it appears as a state of the USA, while in others as a foreign country. However, policy makers in Puerto Rico assume the economy of the island, whose international trade is mostly with the USA, is small, open and fully dollarized. In this context, it can be considered a price taker economy.

Despite the influence of the USA on the monetary policy inflation of Puerto Rico, Rodriguez (2004) indicates that inflation in the island originates more on the supply side than the demand side. He notes that the population density and the legal status with the USA (among these may be mentioned; "Ley de Cabotaje" and minimum wage) are transferred in meaningful and sustainable changes in the price level. He also notes that part of the local assets have been liquidated to consumption, also generating inflationary pressures. Regardless of the monetary policy implemented in the USA, there are inflationary pressures on the factors of production costs, such as wages and raw materials costs that may have destabilizing consequences in the economy of Puerto Rico. According to this conjecture, the causes of inflation in Puerto Rico are given more noticeably on the side of the costs than on the demand.

On the other hand, by analyzing time series using different methodologies indicated that inflation is a monetary phenomenon associated with movements of the amount of money in USA (Rodriguez 2002, Toledo 2002). Nevertheless, analyzing the Near-Var model in which the relations of the variables are based on a difference equations model, (Rodriguez and Toledo 2007) argued that "... the inflationary effects that may have political USA monetary depend on the use of the Taylor rule. It means that when this rule is used, a significant portion of the deviations from the inflation rate from its long run trend of growth is explained by the impulses in the interest, which does not happen when the observed values of the variable are used ...." However, they also indicated that regardless of the 
monetary policy applied in the USA, this will be transmitted, short-term, in prices and in the long-run to the real sector. According to Rodriguez (2002) "... this nonneutrality of money in the long-run can be given because nominal wages are not increased proportionally to the expansion in the monetary supply and these are not indexed to inflation, given the existence of market imperfections and by the particular conditions that characterize the monetary policy in Puerto Rico".

Estrella (2005) noted that the development of the financial sector in the USA has played an important role in the growth of the economy of Puerto Rico. According to the empirical evidence presented, this is due to the close connection between financial markets and institutions in Puerto Rico and the USA as well as the relatively easy access of local businesses to capital markets in the USA. However, Rodriguez (2002) noted that the USA's financial wealth has a positive effect on consumption and its effects are symmetrical with the CPI. According to the author, the above reflect that on the island there is no difference between the behavior of the price indexes in the real sector and those corresponding to the USA financial system. Also, the rise in prices and the creation of higher financial assets in real terms in periods of economic growth are associated with correspondence to the USA financial wealth increase.

Rodriguez (2005) found that real money demand shows a stable relationship with the local economic activity and the monetary policy implemented by the Federal Reserve. According to this study, economic activity is elastic with respect to the money real balances as there is a higher money demand for transactions, given the high consumption level in Puerto Rico. Moreover, he found that the interest rate has a negative and less than proportional relationship over real money balances, because financial savings are adjusted in line with expectations of the USA monetary policy, which tends to decrease during periods of high inflation.

Although, Puerto Rico does not have a Central Bank, the existence of market imperfections and the specific conditions that characterize their monetary sector, Alameda (2000) points out that economy can have a significant effect in the control of money through the credit activity. Therefore, it can also be argued that a credit expansion may have effects on the level of real income (Estrella 2005, Alameda 2000). Rodriguez (2002) for his part noted that the economy of Puerto Rico has a general behavior IS-LM model with market imperfections. It may indicate the existence of a core of variables that maintain a long-term balanced relationship that can be used as a strategic axis for building any macroeconomic model for Puerto Rico.

\section{Comparative Analysis of the Series of Inflation (January 1981-June 2007)}

Inflation is calculated by the consumer price index prepared by the Department of Labor and Human Resources and consists of the monthly period January 1980 to June 2007. One series of inflation has a 1984 base year and the other has a 2006 base year. 
There are significant differences between stationary series and nonstationary series. The stationary time series shocks are transient and the series revert to its long-term behavior. Moreover, in non-stationary series the mean, variance or both are functions of time and there is not a mean value in the longrun series which can return. The variance tends to infinity as time also does and the values corresponding to the lags of the autocorrelation function (ACF) of the series decrease slowly.

The first aspect to consider is the long-term behavior of the series. A graphical inspection of the series gives an overview of how it has changed its behavior due to the new methodology.

As shown in Figure 1 in Appendix A (A.1) (inf84 is the inflation series with the previous methodology and inf06 with the current methodology), both series maintain a common trend until the mid-90's in which the gap begins to open. As can be seen, this gap will increase over time; the high volatility of the series built with the previous methodology from mid-2004 is also shown.

Moreover, the new series has a more similar behavior to a stationary series. However, a higher volatility throughout the last years, although not as strong as the other series, is also shown.

The statistical analysis presented in Appendix A (Section A.2.1) shows a difference in the mean, variance and range between the two series. These results, added to the others presented in the Appendix A (Section A.2.2 and A.2.3), show that the series of inflation calculated CPI base year 2006 (inf06) is a series with a more stable behavior without oscillations affecting its future development significantly. The calculation inflation with the CPI of the base year 1984 (inf84) shows, at first glance, that the mean, variance and autocovariance are not constant over time. Regarding the inf06 series, this behavior is not noted clearly, reason why further test need to be performed.

The correlogram is used as an initial analysis to observe if the series studied are stationary or non-stationary. A slow decline in the ACF indicates high values of the characteristic roots, unit root process or a stationary trend process (Enders 1995). Because of the way the correlogram of both series decreases exponentially, it is possible that the generating process data is an autoregressive process of order AR (p) (See Appendix A (Section A.3).

However, it is noted that the values corresponding to both correlogrograms begin to enter the intervals of confidence at significantly different lags. The correlogram of the series inf84 shows that up to lag 25 none of the values of the ACF entered the confidence interval. Nevertheless, with inf06 it is noted that by the lag 12 the ACF entered in the confidence intervals. This means that data series inf06 shows a significantly lower autocorrelation than inf04. However, this test is not conclusive in determining whether there is or not a unit root. The correlogram test has low power to distinguish between being close to a unit root and a process of unit root as may be the case in inf06. This low power happens, because a series close to a unit root shows the same form in the correlogram as the series with unitary roots. More formal tests help determine whether this series contains or not tendencies and whether there are deterministic or stochastic. 
As an initial analysis, an autoregressive AR (1) model was estimated. In the case inf84, the AR (1) model parameter indicates the possibility of a unitary root. Nevertheless, the estimated value of the slope is located 3.06 from the standard deviation, what leans to a non-stationary series. Although it is not right to use this information to determine if there is a unit root, it points out the need to deepen the study of this series. For this, the true distribution of the series must be known, using it to analyze if the series has or not a unitary root (See Appendix A, Section A.4.1 and A.4.2).

The arguments most commonly used are the Dickey Fuller (ADF) and Phillips Perron (PP). It is intended to determine whether the differentiated variable to be studied is presented with a unitary root during its first or other lags.

According to the lag selection criteria for the unit root test, it was decided to use 14 lags for inf84 and 12 lags for inf06 (See Appendix A, Section A.5.1 and A.5.2). The unit root tests are presented with intercept and no lags, with intercepts and lags, with intercepts, tendencies and lags.

For the variable inf84, the proof of the existence of a unit root indicates that is found when the model is presented with lags, without lags, intercepts and slope (See Appendix A, Section A.6.1). However, the differentiated series (dinf84) appears as stationary (See Appendix A, Section A.6.2) in all tests including the no lags test and the 16 lags test (See Appendix A, Section A.5.3).

Regarding the variable inf06 the test without lags shows no unit root, nevertheless, both others indicate the presence of a unitary root. By differentiating the series (dinf06) all tests proved that the differentiated series is stationary (See Appendix A, Sections A.6.3 and A.6.4).

The methodology for determining the existence of a unit root is the same for the three types of equations used. However, there is a need to be careful with the critical values of the " $t$ " test, since they depend on the inclusion of the intercept or tendencies and sample size. For this, an analysis is added to the ADF test by the F-statistic, to test the joint hypothesis of the coefficients, join with the unitary root test. The unit root test is performed with statistical "T (rho-1)", contrary to the previous analysis which was with the " $t$ " test. This is also used to analyze the autoregressive AR (1) equation of the model representing the data generating process (DGP).

According to the results, both series present unit roots in their levels (see Appendix A, section A.7). This is why it is more likely that the resulting DGP for inf84 and inf06 have the following ways (see Appendix A, section A.7):

$$
\begin{aligned}
& \Delta \text { inf } 84_{t}=\alpha_{0}+\alpha_{1} t^{2}+\sum_{i=1}^{16} \gamma_{t-i} \Delta^{2} i n f 84_{t-i}+\epsilon_{i} \\
& \Delta i n f 06_{t}=\beta_{0}+\beta_{1} t+\sum_{i=1}^{9} \gamma_{t-i} \Delta^{2} \text { inf } 06_{t-i}+\mu_{i}
\end{aligned}
$$

A modification of the ADF test is the PP which is similarly analyzed. According to the PP test variable inf 84 has a unit root in the levels of the series (See Appendix A, Section A.6.5). While the differentiated series is not stationary (See Appendix A, Section A.6.6), the DGP in inf84 remained similar for both tests, with perhaps the exception of the tendency. Contrary to what 
was presented regarding the ADF test, the series inf06 turns to be stationary at its level (See Appendix A, Section A.6.7). The DGP proposed under this test might have the following form:

$$
\inf 06_{t}=\beta_{0}+\beta_{1} t+\sum_{i=1}^{9} \gamma_{t-i} \Delta i n f 06_{t-i}+\mu_{i}
$$

These differences in the results of the test and the DGP of the series are due to the closeness of inf06 to have a unitary root in its autoregressive polynomial. It is important to review the dynamic evolution of that series, as it shows characteristics of a unitary root series.

Because the series have a monthly frequency, an alternate procedure needs to be used to investigate if there is an existence of a stationary unit root. The Hylleberg test, Engle, Granger and Yoo (HEGY) were used for both series (See Appendix A, Section A.8.1 and A.8.2). According to the results, there is a unitary root for inf84, but not a stationary unit root. Regarding inf06, the test indicates there is no existence of any type of unitary root. Therefore, it is concluded that the series inf 84 presents a unitary root. However, the series inf06 is a stationary series with a none stationary unit root.

Moreover, according to the high volatility shown by the inf 84 series, by the end of the period, a test of structural break was performed. For this, the PP methodology is used, that shows that the unitary root tests are biased when accepting the invalid hypothesis of a unitary root in presence of a structural breakage. However, the test concludes that the filtered series used in this procedure does not include a unitary root, reason why the unitary root test are not biased by the behavior observed at the last period of inf 84 . The programming of this and other tests were performed on the RATS program.

\section{Conclusions}

During the last seventy years the transformations that occurred in Puerto Rico at an economic level define the behavioral tendencies of the principal macro-econometric variables. Nevertheless, it is also fundamental to include the methodological analysis in the discussion. As shown in this paper, the CPI in Puerto Rico went through one of the most important methodological changes in its history. This change can bring a significant impact on the equation that describes the dynamic behavior of inflation, as well as to the macro-econometric analysis performed over the economy of the island. Although several works recognize the various causes of inflation due to supply and demand, any other methodological change regarding this type of variable should be studied from the dynamic context.

When the tendency behavior of inflation was studied with both methodologies, at the beginning of the study, they showed a similar tendency; however, from the mid-90s the gap between the two is wider. This gap is more noticeable by the mid-2000s. Even the inflation series calculated using old CPI methodology, shows high volatility at the end of the period. Despite the difference 
in both behaviors, the correlogram showed the possibility that the two series could be non-stationary. However, the AR (1) equation, for both series, gave indications that inflation calculated using the new methodology applied to CPI had a very close behavior to a unit root, although this is not conclusive.

When the ADF and PP tests were conducted for both series, inflation calculated from the old methodology applied to the CPI, clearly showed the existence of a unit root in the autoregressive polynomial, but not the series of inflation calculated based on the new CPI methodology. In the ADF test, it came as a series with a unit root and the PP as a stationary series. This is because the series is close to having a unit root. That is, in some cases it shows signs to have a unit root in the autoregressive polynomial and not in others. Therefore, the DGP is not well defined when both tests are performed.

It is more advantageously to have a process where the series is close to have a unit root than to have a series which has a unit root. This is because of the probability that the average and the variance are not in function of time, which leads to more efficient results when working with this type of series. However, given its proximity to have a root unit, it must be periodically analyzed, in order to avoid analysis and estimation process when the series are non-stationary. 
Appendix A

A.1. Inflation graph

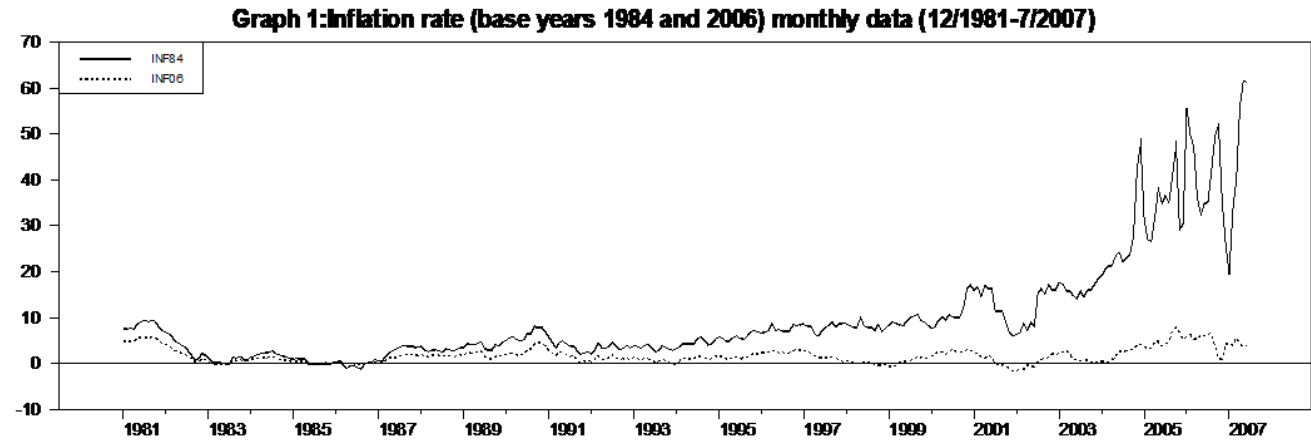

A.2. Statistical analysis

A.2.1. Mean, standard error and minimum and maximum values of the series

\begin{tabular}{|c|c|c|c|c|c|}
\hline Series & Obs & Mean & Std Error & Minimum & Maximum \\
\hline INF84 & 318 & 9.812578616 & 11.695795800 & -1.300000000 & 61.700000000 \\
\hline INF06 & 318 & 1.708176101 & 1.701618400 & -1.680000000 & 7.870000000 \\
\hline
\end{tabular}

A.2.2. Statistics on Series INF84

Monthly Data From 1981:01 to 2007:06

\begin{tabular}{|l|c|l|c|}
\hline Observations & 318 & & \\
\hline Sample Mean & 9.812579 & Variance & 136.791639 \\
\hline Standard Error & 11.695796 & SE of Sample Mean & 0.655868 \\
\hline t-Statistic (Mean=0) & 14.961217 & Signif Level $($ Mean=0) & 0.000000 \\
\hline Skewness & 2.267683 & Signif Level $(\mathbf{S k = 0})$ & 0.000000 \\
\hline Kurtosis (excess) & 5.184100 & Signif Level $(\mathbf{K u = 0})$ & 0.000000 \\
\hline Jarque-Bera & 628.638849 & Signif Level $(\mathbf{J B}=\mathbf{0})$ & 0.000000 \\
\hline
\end{tabular}

A.2.3. Statistics on Series INF06

\begin{tabular}{|l|c|l|l|}
\hline Monthly Data From 1981:01 To 2007:06 & \\
\hline Observations & 318 & & 2.895505 \\
\hline Sample Mean & 1.708176 & Variance & 0.095422 \\
\hline Standard Error & 1.701618 & SE of Sample Mean & 0.000000 \\
\hline t-Statistic (Mean=0) & 17.901278 & Signif Level $(\mathbf{M e a n}=\mathbf{0})$ & 0.000000 \\
\hline Skewness & 1.024112 & Signif Level $(\mathbf{S k = 0})$ & 0.000594 \\
\hline Kurtosis (excess) & 0.954010 & Signif Level $(\mathbf{K u}=\mathbf{0})$ & 0.000000 \\
\hline Jarque-Bera & 67.646015 & Signif Level $(\mathbf{J B}=\mathbf{0})$ & \\
\hline
\end{tabular}

A.3. Series Correlogram

A.3.1. inf 84

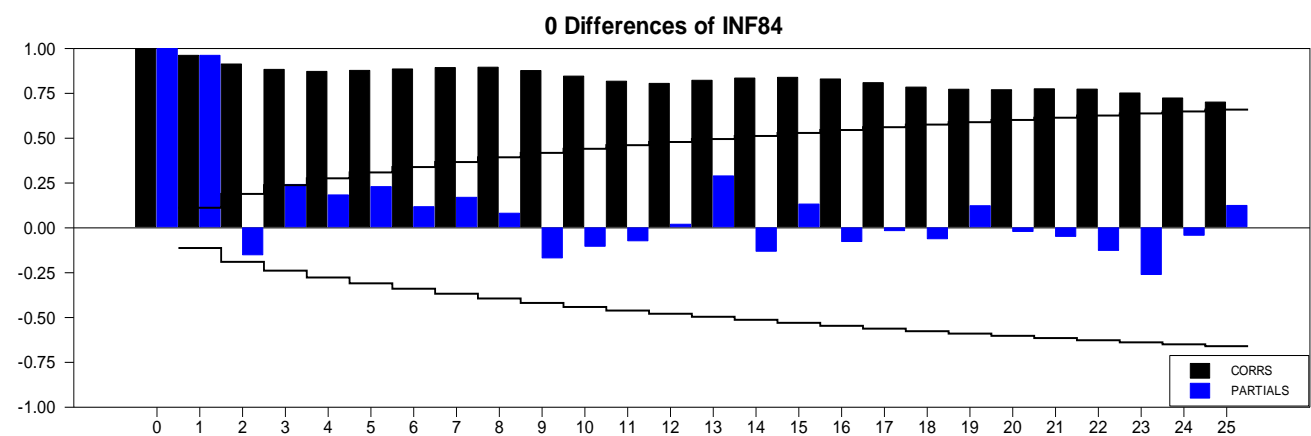


A.3.2. inf06

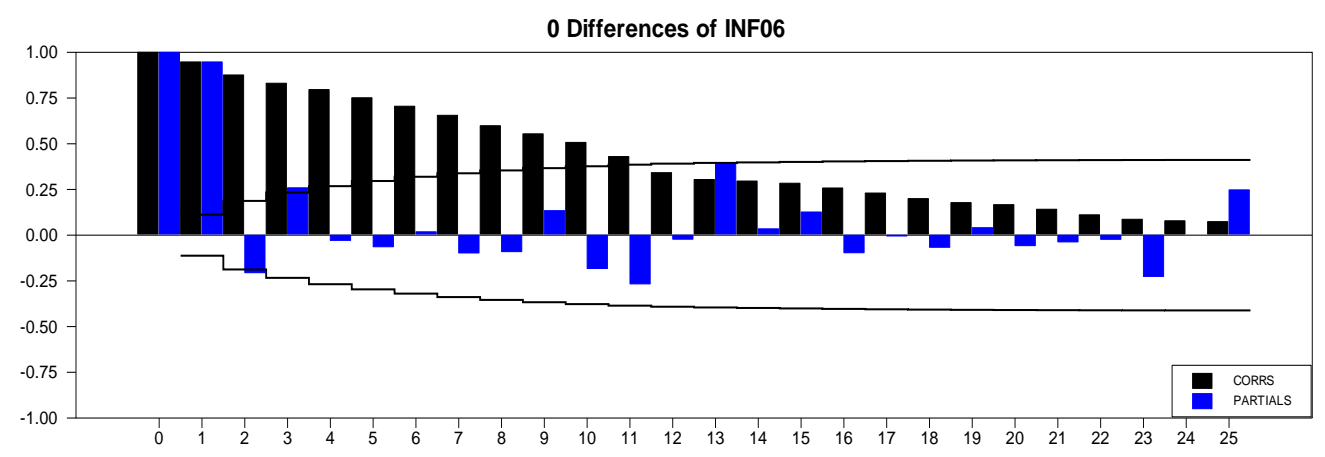

A.4. AR(1) model for both series

A.4.1. inf 84

\begin{tabular}{|c|c|c|c|c|c|}
\hline \multicolumn{6}{|c|}{ Linear Regression - Estimation by Least Squares } \\
\hline \multicolumn{6}{|c|}{ Monthly Data From 1981:02 To 2007:06 } \\
\hline \multicolumn{3}{|c|}{ Usable Observations } & \multicolumn{3}{|l|}{317} \\
\hline \multicolumn{3}{|c|}{ Degrees of Freedom } & \multicolumn{3}{|c|}{316} \\
\hline \multicolumn{3}{|c|}{ Centered $\mathrm{R}^{\wedge} 2$} & \multicolumn{3}{|c|}{0.9263241} \\
\hline \multicolumn{3}{|c|}{$\mathrm{R}-\mathrm{Bar}^{\wedge} 2$} & \multicolumn{3}{|c|}{0.9263241} \\
\hline \multicolumn{3}{|c|}{ Uncentered $\mathrm{R}^{\wedge} 2$} & \multicolumn{3}{|c|}{0.9567890} \\
\hline \multicolumn{3}{|c|}{ Mean of Dependent Variable } & \multicolumn{3}{|c|}{9.819873817} \\
\hline \multicolumn{3}{|c|}{ Std Error of Dependent Variable } & \multicolumn{3}{|c|}{11.713562516} \\
\hline \multicolumn{3}{|c|}{ Standard Error of Estimate } & \multicolumn{3}{|c|}{3.179447486} \\
\hline \multicolumn{3}{|c|}{ Sum of Squared Residuals } & \multicolumn{3}{|c|}{3194.4080757} \\
\hline \multicolumn{3}{|c|}{ Log Likelihood } & \multicolumn{3}{|c|}{-815.9790} \\
\hline \multicolumn{2}{|c|}{ Durbin-Watson Statistic } & & \multicolumn{3}{|c|}{1.7385} \\
\hline Variable & Coeff & Std Erro & & T-Stat & Signif \\
\hline INF84\{1\} & 1.0036035892 & 0.011997 & 9637 & 83.64783 & 0.00000000 \\
\hline
\end{tabular}

A.4.2. inf06

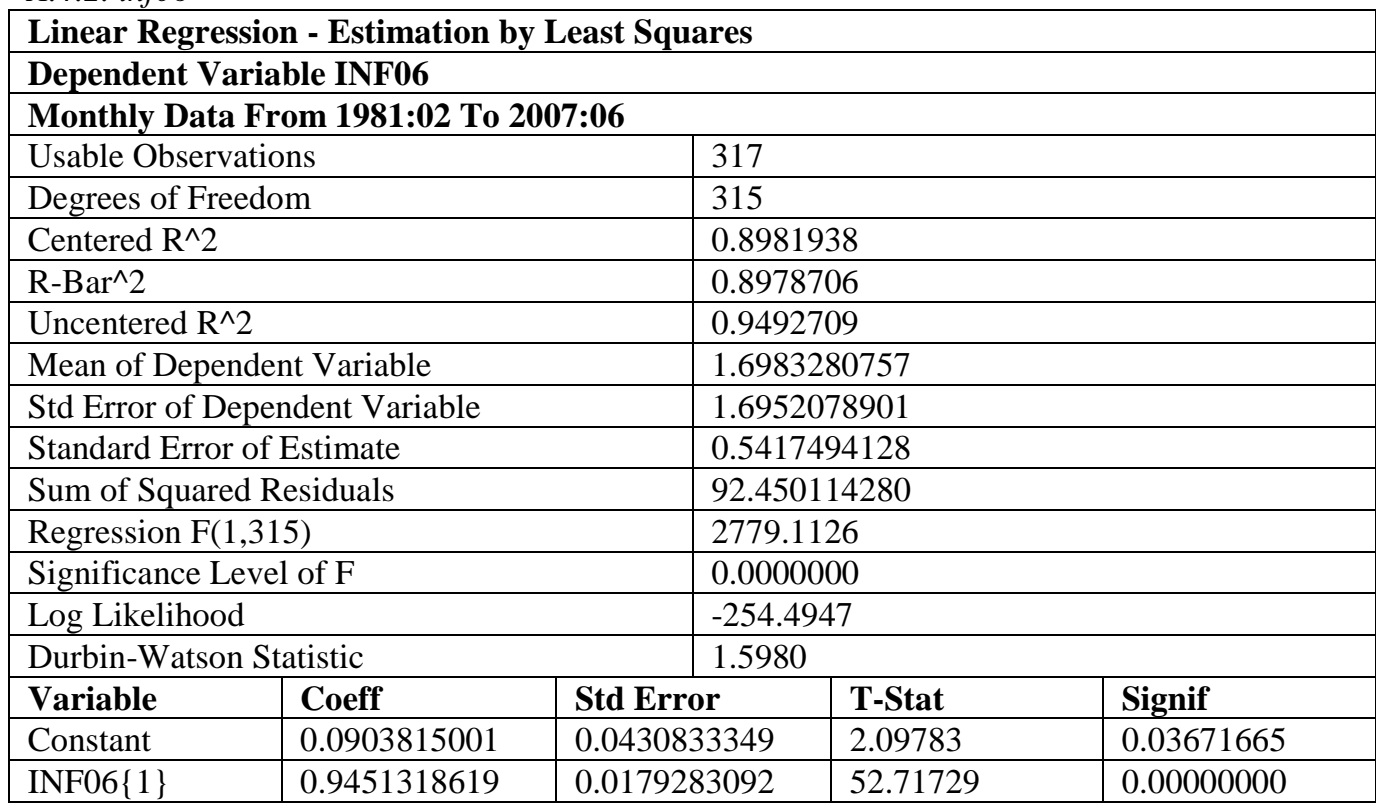


A.5. Lags selection

A.5.1. inf84

Information Criteria for ADF Lag Lengths, Series INF84

\begin{tabular}{|l|l|l|l|l|l|}
\hline Lags & AIC & BIC & HQ & MAIC & ADF \\
\hline 0 & 2.370 & 2.394 & 2.379 & 2.358 & -0.428 \\
\hline 1 & 2.356 & 2.393 & 2.371 & 2.351 & -1.054 \\
\hline 2 & 2.294 & 2.344 & 2.314 & 2.281 & 0.081 \\
\hline 3 & 2.261 & 2.323 & 2.286 & 2.252 & 0.730 \\
\hline 4 & 2.203 & 2.276 & 2.232 & 2.208 & 1.508 \\
\hline 5 & 2.189 & 2.275 & 2.223 & 2.204 & 1.833 \\
\hline 6 & 2.152 & 2.250 & 2.191 & 2.187 & 2.361 \\
\hline 7 & 2.142 & 2.253 & 2.186 & 2.193 & 2.694 \\
\hline 8 & 2.124 & 2.247 & 2.173 & 2.152 & 2.105 \\
\hline 9 & 2.116 & 2.252 & 2.170 & 2.131 & 1.704 \\
\hline 10 & 2.112 & 2.260 & 2.171 & 2.117 & 1.335 \\
\hline 11 & 2.118 & 2.278 & 2.182 & 2.125 & 1.391 \\
\hline 12 & 1.987 & 2.160 & 2.056 & 2.060 & 2.795 \\
\hline 13 & 1.993 & 2.178 & 2.067 & 2.057 & 2.596 \\
\hline 14 & $1.933^{*}$ & $2.130^{*}$ & $2.012^{*}$ & 2.073 & 3.548 \\
\hline 15 & 1.936 & 2.145 & 2.020 & $2.052^{*}$ & 3.159 \\
\hline 16 & 1.943 & 2.164 & 2.031 & 2.059 & 3.038 \\
\hline
\end{tabular}

A.5.2. inf06

\begin{tabular}{|l|l|l|l|l|l|}
\hline \multicolumn{7}{|l}{ Information Criteria for ADF Lag Lengths, Series INF06 } \\
\hline Lags & AIC & BIC & HQ & MAIC & ADF \\
\hline 0 & -1.193 & -1.169 & -1.183 & -1.149 & -2.933 \\
\hline 1 & -1.230 & -1.193 & -1.216 & -1.153 & -3.611 \\
\hline 2 & -1.298 & -1.249 & -1.278 & -1.263 & -2.583 \\
\hline 3 & -1.292 & -1.231 & -1.268 & -1.253 & -2.624 \\
\hline 4 & -1.289 & -1.215 & -1.259 & -1.243 & -2.744 \\
\hline 5 & -1.283 & -1.196 & -1.248 & -1.240 & -2.619 \\
\hline 6 & -1.287 & -1.188 & -1.247 & -1.230 & -2.880 \\
\hline 7 & -1.289 & -1.178 & -1.245 & -1.220 & -3.092 \\
\hline 8 & -1.304 & -1.180 & -1.254 & -1.254 & -2.670 \\
\hline 9 & -1.336 & -1.201 & -1.282 & -1.256 & -3.210 \\
\hline 10 & -1.414 & -1.267 & -1.355 & -1.246 & -4.358 \\
\hline 11 & -1.409 & -1.249 & -1.345 & -1.225 & -4.340 \\
\hline 12 & -1.591 & $-1.419^{*}$ & $-1.522^{*}$ & -1.541 & -2.365 \\
\hline 13 & -1.586 & -1.402 & -1.513 & -1.544 & -2.163 \\
\hline 14 & -1.598 & -1.401 & -1.519 & $-1.573 *$ & -1.744 \\
\hline 15 & $-1.601 *$ & -1.392 & -1.518 & -1.562 & -2.016 \\
\hline 16 & -1.596 & -1.374 & -1.507 & -1.551 & -2.089 \\
\hline
\end{tabular}

A.5.3. $\operatorname{dinf} 84$

\begin{tabular}{|l|l|l|l|l|l|}
\hline Information Criteria for ADF Lag Lengths, Series DINF84 \\
\hline Lags & AIC & BIC & HQ & MAIC & ADF \\
\hline 0 & 2.356 & 2.381 & 2.366 & $3.882 *$ & -15.142 \\
\hline 1 & 2.291 & 2.328 & 2.306 & 4.923 & -14.878 \\
\hline 2 & 2.259 & 2.309 & 2.279 & 6.246 & -13.461 \\
\hline 3 & 2.206 & 2.268 & 2.231 & 8.939 & -13.300 \\
\hline 4 & 2.196 & 2.270 & 2.226 & 11.570 & -11.007 \\
\hline 5 & 2.166 & 2.253 & 2.201 & 17.138 & -10.768 \\
\hline 6 & 2.162 & 2.260 & 2.201 & 21.551 & -9.652 \\
\hline 7 & 2.135 & 2.246 & 2.179 & 15.367 & -6.879 \\
\hline
\end{tabular}




\begin{tabular}{|l|l|l|l|l|l|}
\hline 8 & 2.122 & 2.246 & 2.171 & 12.007 & -5.472 \\
\hline 9 & 2.114 & 2.250 & 2.169 & 9.872 & -4.607 \\
\hline 10 & 2.121 & 2.269 & 2.180 & 10.048 & -4.485 \\
\hline 11 & 2.011 & 2.171 & 2.075 & 17.662 & -6.088 \\
\hline 12 & 2.012 & 2.185 & 2.081 & 15.461 & -5.264 \\
\hline 13 & 1.972 & 2.158 & 2.047 & 23.211 & -6.265 \\
\hline 14 & 1.966 & 2.164 & 2.045 & 18.714 & -5.181 \\
\hline 15 & 1.971 & 2.180 & 2.055 & 17.154 & -4.706 \\
\hline 16 & $1.930^{*}$ & $2.152^{*}$ & $2.019^{*}$ & 11.859 & -3.665 \\
\hline
\end{tabular}

\section{A.5.4. $\operatorname{dinf06}$}

\begin{tabular}{|l|l|l|l|l|l|}
\hline \multicolumn{7}{|l}{ Information Criteria for ADF Lag Lengths, Series DINF06 } \\
\hline Lags & AIC & BIC & HQ & MAIC & ADF \\
\hline 0 & -1.191 & -1.166 & -1.181 & 0.214 & -14.538 \\
\hline 1 & -1.280 & -1.243 & -1.265 & 1.354 & -15.167 \\
\hline 2 & -1.273 & -1.224 & -1.254 & 1.370 & -11.358 \\
\hline 3 & -1.268 & -1.206 & -1.243 & 1.230 & -9.232 \\
\hline 4 & -1.264 & -1.190 & -1.234 & 1.511 & -8.586 \\
\hline 5 & -1.263 & -1.176 & -1.228 & 1.140 & -7.169 \\
\hline 6 & -1.261 & -1.162 & -1.221 & 0.823 & -6.126 \\
\hline 7 & -1.283 & -1.172 & -1.239 & 1.612 & -6.818 \\
\hline 8 & -1.305 & -1.181 & -1.255 & 0.808 & -5.450 \\
\hline 9 & -1.354 & -1.218 & -1.300 & $0.000^{*}$ & -4.177 \\
\hline 10 & -1.349 & -1.201 & -1.290 & 0.105 & -4.213 \\
\hline 11 & -1.575 & $-1.415^{*}$ & -1.511 & 2.184 & -6.567 \\
\hline 12 & -1.573 & -1.400 & -1.504 & 2.732 & -6.559 \\
\hline 13 & -1.590 & -1.405 & $-1.516^{*}$ & 4.262 & -7.122 \\
\hline 14 & $-1.590^{*}$ & -1.393 & -1.511 & 3.388 & -6.053 \\
\hline 15 & -1.584 & -1.374 & -1.500 & 3.286 & -5.631 \\
\hline 16 & -1.583 & -1.360 & -1.494 & 2.624 & -4.963 \\
\hline
\end{tabular}

A.6. Unit root tests

A.6.1. Dickey-Fuller Unit Root Test, Series INF84

\begin{tabular}{|l|l|}
\hline \multicolumn{2}{|l|}{ Regression Run From 1981:02 to 2007:06 } \\
\hline Observations & 318 \\
\hline With intercept & \\
\hline Using fixed lags & 0 \\
\hline Sig Level & Crit Value \\
\hline $1 \%(* *)$ & -3.45265 \\
\hline $5 \%(*)$ & -2.87079 \\
\hline $10 \%$ & -2.57167 \\
\hline T-Statistic & -0.41486 \\
\hline
\end{tabular}

\begin{tabular}{|l|l|}
\hline \multicolumn{2}{|l|}{ Regression Run From 1982:04 to 2007:06 } \\
\hline Observations & 304 \\
\hline With intercept & \\
\hline Using fixed lags & 14 \\
\hline Sig Level & Crit Value \\
\hline $1 \%(* *)$ & -3.45355 \\
\hline $5 \%(*)$ & -2.87120 \\
\hline $10 \%$ & -2.57188 \\
\hline T-Statistic & 3.55744 \\
\hline
\end{tabular}




\begin{tabular}{|l|l|}
\hline \multicolumn{2}{|l|}{ Regression Run From 1982:04 to 2007:06 } \\
\hline Observations & 304 \\
\hline With intercept and trend & \\
\hline Using fixed lags & 14 \\
\hline Sig Level & Crit Value \\
\hline $1 \%(* *)$ & -3.99179 \\
\hline $5 \%(*)$ & -3.42608 \\
\hline $10 \%$ & -3.13594 \\
\hline T-Statistic & 1.05987 \\
\hline
\end{tabular}

A.6.2. Dickey-Fuller Unit Root Test, Series DINF84

\begin{tabular}{|l|l|}
\hline Regression Run From 1981:03 to 2007:06 \\
\hline Observations & 317 \\
\hline With intercept & \\
\hline Using fixed lags & 0 \\
\hline Sig Level & Crit Value \\
\hline $1 \%(* *)$ & -3.4527 \\
\hline $5 \%(*)$ & -2.8708 \\
\hline $10 \%$ & -2.5717 \\
\hline T-Statistic & $-15.5227^{* *}$ \\
\hline
\end{tabular}

\begin{tabular}{|l|l|}
\hline \multicolumn{2}{|l|}{ Regression Run From 1982:07 to 2007:06 } \\
\hline Observations & 301 \\
\hline With intercept & \\
\hline Using fixed lags & 16 \\
\hline Sig Level & Crit Value \\
\hline $1 \%(* *)$ & -3.45375 \\
\hline $5 \%(*)$ & -2.87129 \\
\hline $10 \%$ & -2.57193 \\
\hline T-Statistic & $-3.66512^{* *}$ \\
\hline
\end{tabular}

\begin{tabular}{|l|l|}
\hline \multicolumn{2}{|l|}{ Regression Run From 1982:07 to 2007:06 } \\
\hline Observations & 301 \\
\hline With intercept and trend & \\
\hline Using fixed lags & 16 \\
\hline Sig Level & Crit Value \\
\hline $1 \%(* *)$ & -3.99207 \\
\hline $5 \%(*)$ & -3.42622 \\
\hline $10 \%$ & -3.13602 \\
\hline T-Statistic & $-4.52214^{* *}$ \\
\hline
\end{tabular}

A.6.3. Dickey-Fuller Unit Root Test, Series INF06

\begin{tabular}{|l|l|}
\hline Regression Run From 1981:02 to 2007:06 \\
\hline Observations & 318 \\
\hline With intercept & \\
\hline Using fixed lags & 0 \\
\hline Sig Level & Crit Value \\
\hline $1 \%(* *)$ & -3.45265 \\
\hline $5 \%(*)$ & -2.87079 \\
\hline $10 \%$ & -2.57167 \\
\hline T-Statistic & $-3.06042^{*}$ \\
\hline
\end{tabular}




\begin{tabular}{|l|l|}
\hline Regression Run From 1982:02 to 2007:06 \\
\hline Observations & 306 \\
\hline With intercept & \\
\hline Using fixed lags & 12 \\
\hline Sig Level & Crit Value \\
\hline $1 \%(* *)$ & -3.45342 \\
\hline $5 \%(*)$ & -2.87114 \\
\hline $10 \%$ & -2.57185 \\
\hline T-Statistic & -2.72079 \\
\hline
\end{tabular}

\begin{tabular}{|l|l|}
\hline Regression Run From 1982:02 to 2007:06 \\
\hline Observations & 306 \\
\hline With intercept and trend & \\
\hline Using fixed lags & 12 \\
\hline Sig Level & Crit Value \\
\hline $1 \%(* *)$ & -3.99160 \\
\hline $5 \%(*)$ & -3.42599 \\
\hline $10 \%$ & -3.13588 \\
\hline T-Statistic & -3.31720 \\
\hline
\end{tabular}

A.6.4. Dickey-Fuller Unit Root Test, Series DINF06

\begin{tabular}{|l|l|}
\hline Regression Run From 1981:03 to 2007:06 \\
\hline Observations & 317 \\
\hline With intercept & \\
\hline Using fixed lags & 0 \\
\hline Sig Level & Crit Value \\
\hline $1 \%(* *)$ & -3.4527 \\
\hline $5 \%(*)$ & -2.8708 \\
\hline $10 \%$ & -2.5717 \\
\hline T-Statistic & $-14.7605^{* *}$ \\
\hline
\end{tabular}

\begin{tabular}{|l|l|}
\hline Regression Run From 1981:12 to 2007:06 \\
\hline Observations & 308 \\
\hline With intercept & \\
\hline Using fixed lags & 9 \\
\hline Sig Level & Crit Value \\
\hline $1 \%(* *)$ & -3.45329 \\
\hline $5 \%(*)$ & -2.87108 \\
\hline $10 \%$ & -2.57182 \\
\hline T-Statistic & $-3.97520^{* *}$ \\
\hline
\end{tabular}

\begin{tabular}{|l|l|}
\hline Regression Run From 1981:12 to 2007:06 \\
\hline Observations & 308 \\
\hline With intercept and trend & \\
\hline Using fixed lags & 9 \\
\hline Sig Level & Crit Value \\
\hline $1 \%(* *)$ & -3.99142 \\
\hline $5 \%(*)$ & -3.42590 \\
\hline $10 \%$ & -3.13583 \\
\hline T-Statistic & $-4.03091^{* *}$ \\
\hline
\end{tabular}


A.6.5. Phillips-Perron Test for a Unit Root for INF84

\section{Regression Run From 1981:02 to 2007:06}

Observations

With intercept

Sig Level

$1 \%(* *)$

$5 \%(*)$

$10 \%$

Lags

0

\begin{tabular}{|l|l|}
\hline \multicolumn{2}{|l|}{ Regression Run From 1981:02 to 2007:06 } \\
\hline Observations & 317 \\
\hline With intercept & \\
\hline Sig Level & Crit Value \\
\hline $1 \%(* *)$ & -3.45265 \\
\hline $5 \%(*)$ & -2.87079 \\
\hline $10 \%$ & -2.57167 \\
\hline Lags & Statistic \\
\hline 14 & 1.53819 \\
\hline
\end{tabular}

\section{Regression Run From 1981:02 to 2007:06}

Observations

With intercept and trend

Sig Level

$1 \%(* *)$

$5 \%(*)$

$10 \%$

Lags

14

\begin{tabular}{|l|l|}
\hline & 317 \\
\hline Crit Value \\
\hline-3.45265 \\
\hline-2.87079 \\
\hline-2.57167 \\
\hline Statistic \\
\hline-0.41617 \\
\hline
\end{tabular}

A.6.6.Phillips-Perron Test for a Unit Root for DINF84

Regression Run From 1981:03 to 2007:06

\begin{tabular}{|l|l|}
\hline Observations & 316 \\
\hline With intercept & \\
\hline Sig Level & Crit Value \\
\hline $5 \%(*)$ & -3.4527 \\
\hline $10 \%$ & -2.8708 \\
\hline Lags & -2.5717 \\
\hline 0 & Statistic \\
\hline & $-15.5720^{* *}$ \\
\hline
\end{tabular}

\begin{tabular}{|l|l|}
\hline \multicolumn{2}{|l|}{ Regression Run From 1981:03 to 2007:06 } \\
\hline Observations & 316 \\
\hline With intercept & \\
\hline Sig Level & Crit Value \\
\hline $1 \%(* *)$ & -3.4527 \\
\hline $5 \%(*)$ & -2.8708 \\
\hline $10 \%$ & -2.5717 \\
\hline Lags & Statistic \\
\hline 16 & $-17.0642^{* *}$ \\
\hline
\end{tabular}




\begin{tabular}{|l|l|}
\hline Regression Run From 1981:03 to 2007:06 \\
\hline Observations & 316 \\
\hline With intercept and trend & \\
\hline Sig Level & Crit Value \\
\hline $1 \%(* *)$ & -3.9906 \\
\hline $5 \%(*)$ & -3.4255 \\
\hline $10 \%$ & -3.1356 \\
\hline Lags & Statistic \\
\hline 16 & $-18.1388^{* *}$ \\
\hline
\end{tabular}

A.6.7. Phillips-Perron Test for a Unit Root for INF06

\begin{tabular}{|l|l|}
\hline Regression Run From 1981:02 to 2007:06 \\
\hline Observations & 317 \\
\hline With intercept & \\
\hline Sig Level & Crit Value \\
\hline $1 \%(* *)$ & -3.45265 \\
\hline $5 \%(*)$ & -2.87079 \\
\hline $10 \%$ & -2.57167 \\
\hline Lags & Statistic \\
\hline 0 & $-3.07012^{*}$ \\
\hline
\end{tabular}

\begin{tabular}{|l|l|}
\hline Regression Run From 1981:02 to 2007:06 \\
\hline Observations & 317 \\
\hline With intercept & \\
\hline Sig Level & Crit Value \\
\hline $1 \%(* *)$ & -3.45265 \\
\hline $5 \%(*)$ & -2.87079 \\
\hline $10 \%$ & -2.57167 \\
\hline Lags & Statistic \\
\hline 12 & $-3.32177^{*}$ \\
\hline
\end{tabular}

\begin{tabular}{|l|l|}
\hline Regression Run From 1981:02 to 2007:06 \\
\hline Observations & 317 \\
\hline With intercept and trend & \\
\hline Sig Level & Crit Value \\
\hline $1 \%(* *)$ & -3.99054 \\
\hline $5 \%(*)$ & -3.42548 \\
\hline $10 \%$ & -3.13558 \\
\hline Lags & Statistic \\
\hline 12 & $-3.48292^{*}$ \\
\hline
\end{tabular}

A.7. Unit root and detrministics component significancy tests A.7.1. inf84 (ADF)

@URAUTO Procedure by Paco Goerlich

Testing series: INF84 Sample 1981:01 to 2007:06

Autoregressive corrections: 14 lags

Working at 5.0\% significance level

All tests of unit root are one-sided.

Regressions with constant, trend

t-tau statistic for rho $=1 \quad 1.05987$ with critical value -3.41000

Cannot reject a unit root $\mathrm{t}$-statistic 
Next is joint test of trend $=0$ and root $=1$

psi3 $=8.02773$ with critical value 6.25000

psi3 significant

Next, test trend $=0$ given root $=1$

trend $=0$ test $=3.86338$ using normal distribution

Trend significant under the unit root.

Conclusion: Cannot reject unit root. Try quadratic trend alternative

A.7.2. $\operatorname{dinf84}(A D F)$

@URAUTO Procedure by Paco Goerlich

Testing series: DINF84 Sample 1981:02 to 2007:06

Autoregressive corrections: 16 lags

Working at $5.0 \%$ significance level

All tests of unit root are one-sided.

Regressions with constant, trend

t-tau statistic for rho $=1 \quad-4.52214$ with critical value -3.41000

Unit root rejected with $\mathrm{t}$-statistic

Conclusion: Series has no unit root, but possibly a linear trend

A.7.3. info6 (ADF)

@URAUTO Procedure by Paco Goerlich

Testing series: INF06

Sample 1981:01 to 2007:06

Autoregressive corrections: 12 lags

Working at $5.0 \%$ significance level

All tests of unit root are one-sided.

Regressions with constant, trend

$\mathrm{t}$-tau statistic for rho $=1 \quad-3.31720$ with critical value -3.41000

Cannot reject a unit root t-statistic

Next is joint test of trend $=0$ and root $=1$

psi3 $=6.49655$ with critical value 6.25000

psi3 significant

Next, test trend $=0$ given root $=1$

trend $=0$ test $=1.38679$ using normal distribution

Trend insignificant under the unit root. Unit root cannot be rejected

Testing for constant (drift) $=0$

psi2 $=4.33233$ with critical value 4.68000

drift $=0$ accepted

Conclusion: Series contains a unit root with zero drift

A.7.4. dinf06 (ADF)

@URAUTO Procedure by Paco Goerlich

Testing series: DINF06 Sample 1981:02 to 2007:06

Autoregressive corrections: 9 lags

Working at $5.0 \%$ significance level

All tests of unit root are one-sided. 
Regressions with constant, trend

t-tau statistic for rho $=1 \quad-4.03091$ with critical value -3.41000

Unit root rejected with t-statistic

Conclusion: Series has no unit root, but possibly a linear trend

A.7.5. inf84 (PP)

@URAUTO Procedure by Paco Goerlich

Testing series: INF84 Sample 1981:01 to 2007:06

Non-parametric corrections. Window size: 14

Working at $5.0 \%$ significance level

All tests of unit root are one-sided.

Regressions with constant, trend

t-tau statistic for rho $=1 \quad-1.05962$ with critical value -3.41000

Cannot reject a unit root t-statistic

Next is joint test of trend $=0$ and root $=1$

psi3 $=2.47611$ with critical value 6.25000

psi3 cannot reject unit root and no linear trend

Regressions with constant, no trend

t-mu statistic for rho $=1 \quad 1.54708$ with critical value -2.86000

Cannot reject a unit root with t-mu

Next is joint test of constant $=0$ and root $=1$

psi1 $=2.25066$ with critical value 4.59000

psi1 cannot reject constant $=0$ and root $=1$

Regressions with no constant, no trend

$\mathrm{t}$-rho statistic for rho $=1 \quad 2.53211$ with critical value -1.95000

Cannot reject a unit root with t-rho

Conclusion: Series contains a unit root with zero drift

A.7.6. $\operatorname{dinf84}(P P)$

@URAUTO Procedure by Paco Goerlich

Testing series: DINF84 Sample 1981:02 to 2007:06

Non-parametric corrections. Window size: 16

Working at $5.0 \%$ significance level

All tests of unit root are one-sided.

Regressions with constant, trend

$\mathrm{t}$-tau statistic for rho $=1 \quad-17.92576$ with critical value -3.41000

Unit root rejected with t-statistic

Conclusion: Series has no unit root, but possibly a linear trend

A.7.7. info6 (PP)

@URAUTO Procedure by Paco Goerlich

Testing series: INF06 Sample 1981:01 to 2007:06

Non-parametric corrections. Window size: 12

Working at $5.0 \%$ significance level 
All tests of unit root are one-sided.

Regressions with constant, trend

$\mathrm{t}$-tau statistic for rho $=1 \quad-3.47004$ with critical value -3.41000

Unit root rejected with t-statistic

Conclusion: Series has no unit root, but possibly a linear trend

A.8.1. HEGY test (inf84)

\begin{tabular}{|l|l|}
\hline \multicolumn{2}{|l|}{ Linear Regression - Estimation by Least Squares } \\
\hline Dependent Variable Y4 \\
\hline Monthly Data From 1982:02 To 2007:06 \\
\hline Usable Observations & 260 \\
\hline Degrees of Freedom & 256 \\
\hline Skipped/Missing (from 305) & 45 \\
\hline Centered R^2 & 0.5919404 \\
\hline R-Bar^2 & 0.5871585 \\
\hline Uncentered R^2 & 0.5934125 \\
\hline Mean of Dependent Variable & 0.0412909052 \\
\hline Std Error of Dependent Variable & 0.6875346159 \\
\hline Standard Error of Estimate & 0.4417598709 \\
\hline Sum of Squared Residuals & 49.958856585 \\
\hline Log Likelihood & -154.4914 \\
\hline Durbin-Watson Statistic & 1.4814 \\
\hline
\end{tabular}

\begin{tabular}{|l|l|l|l|l|}
\hline Variable & Coeff & Std Error & T-Stat & Signif \\
\hline Y1 $\{1\}$ & 0.0016222199 & 0.0010793769 & 1.50292 & 0.13409157 \\
\hline Y2\{2\} & 0.4892685018 & 0.0827974490 & 5.90922 & 0.00000001 \\
\hline Y3 $\{1\}$ & 0.6130020070 & 0.1160627133 & 5.28164 & 0.00000027 \\
\hline Y3 $\{2\}$ & 0.3233279343 & 0.1205601356 & 2.68188 & 0.00779711 \\
\hline
\end{tabular}

Null Hypothesis: The Following Coefficients are Zero
$\mathrm{Y} 3$
$\operatorname{Lag}(\mathrm{s}) 1$ to 2

$F(2,256)=61.75146$ with Significance Level 0.00000000

A.8.2. HEGY test (inf06)

\begin{tabular}{|l|l|}
\hline \multicolumn{2}{|l|}{ Linear Regression - Estimation by Least Squares } \\
\hline Dependent Variable Y46 \\
\hline Monthly Data From 1982:02 To 2007:06 \\
\hline Usable Observations & 193 \\
\hline Degrees of Freedom & 189 \\
\hline Skipped/Missing (from 305) & 112 \\
\hline Centered R^2 & 0.4342100 \\
\hline R-Bar^2 & 0.4252292 \\
\hline Uncentered R^2 & 0.4360123 \\
\hline Mean of Dependent Variable & -0.065647268 \\
\hline Std Error of Dependent Variable & 1.164327608 \\
\hline Standard Error of Estimate & 0.882719109 \\
\hline Sum of Squared Residuals & 147.26748193 \\
\hline Log Likelihood & -247.7577 \\
\hline Durbin-Watson Statistic & 1.3157 \\
\hline
\end{tabular}




\begin{tabular}{|l|l|l|l|l|}
\hline Variable & Coeff & Std Error & T-Stat & Signif \\
\hline Y16 $\{1\}$ & 0.0026697198 & 0.0066563586 & 0.40108 & 0.68881568 \\
\hline Y26 $\{2\}$ & 0.1740654481 & 0.0797447583 & 2.18278 & 0.03028453 \\
\hline Y36 $\{1\}$ & 0.4904843135 & 0.1191679530 & 4.11591 & 0.00005756 \\
\hline Y36\{2\} & 0.3989494627 & 0.1200606306 & 3.32290 & 0.00106965 \\
\hline
\end{tabular}

Null Hypothesis: The Following Coefficients are Zero

Y36

$\operatorname{Lag}(\mathrm{s}) 1$ to 2

$\mathrm{F}(2,189)=45.34500$ with Significance Level 0.00000000

A.9. Structural break test (inf84)

\begin{tabular}{|l|l|}
\hline \multicolumn{2}{|l|}{ Linear Regression - Estimation by Least Squares } \\
\hline Dependent Variable Y46 \\
\hline Monthly Data From 1982:02 To 2007:06 \\
\hline Usable Observations & 193 \\
\hline Degrees of Freedom & 189 \\
\hline Skipped/Missing (from 305) & 112 \\
\hline Centered R^2 & 0.4342100 \\
\hline R-Bar^2 & 0.4252292 \\
\hline Uncentered R^2 & 0.4360123 \\
\hline Mean of Dependent Variable & -0.065647268 \\
\hline Std Error of Dependent Variable & 1.164327608 \\
\hline Standard Error of Estimate & 0.882719109 \\
\hline Sum of Squared Residuals & 147.26748193 \\
\hline Log Likelihood & -247.7577 \\
\hline Durbin-Watson Statistic & 1.3157 \\
\hline
\end{tabular}

\begin{tabular}{|l|l|l|l|l|}
\hline Variable & Coeff & Std Error & T-Stat & Signif \\
\hline Y16 $\{1\}$ & 0.0026697198 & 0.0066563586 & 0.40108 & 0.68881568 \\
\hline Y26 $\{2\}$ & 0.1740654481 & 0.0797447583 & 2.18278 & 0.03028453 \\
\hline Y36 $\{1\}$ & 0.4904843135 & 0.1191679530 & 4.11591 & 0.00005756 \\
\hline Y36 $\{2\}$ & 0.3989494627 & 0.1200606306 & 3.32290 & 0.00106965 \\
\hline
\end{tabular}

Null Hypothesis: The Following Coefficients are Zero

Y36 $\operatorname{Lag}(\mathrm{s}) 1$ to 2

$\mathrm{F}(2,189)=45.34500$ with Significance Level 0.00000000 


\section{References}

Alameda JI (2000) La política monetaria en Puerto Rico [Monetary policy of Puerto Rico]. In C Mc Connel, S Brue (14 ${ }^{\text {th }}$ eds.), Economía: Versión especial para Puerto Rico [Economy:Special Version Puerto Rico]. New York: Mc Graw Hill.

Catala F (1993) La sección 936: nuevas reglas de juego. Diálogo, Septiembre Octubre, San Juan, Puerto Rico [Section 936: new rules. Dialogue, September October, San Juan, Puerto Rico].

Commerce Department (1979) Report to the President/Prepared by the Interagency Task Force Coordinated by the United States Department of Commerce. Economic Study of Puerto Rico.

Department of Labor and Human Resourses (2010) Nota técnica sobre el índice oficial de precios al consumidor [Technical note on the official consumer price index]. Retrieved from http://goo.gl/Q1SUsd.

Dietz JL (1989) Historia Económica de Puerto Rico [Economic History of Puerto Rico]. Rio Piedras, Puerto Rico: Huracán.

Enders W (1995) Applied Econometrics Time Series (1 $1^{\text {st }}$ eds.). New York: Wiley.

Estrella A (2005) Financial dependence and economic growth in Puerto Rico. Federal Reserve Bank of New York.

Lewis A (1949) Industrial development in Puerto Rico. The Caribbean Economic Review 1(1-2): 153-175.

Perloff HS (1952) The United States and the economic development of Puerto Rico. Journal of Economic History 12(1): 45-59.

Planning Board (1994) Informe Económico al Gobernador [Economic Report to the Governor]. Área de Planificación Económica y Social, Sub-programa de Análisis Económico [Department of Economic and Social Planning, Subprogram of Economic Analysis]. Sección 936: Enmiendas Recientes y posibles impactos [Section 936: Recent Amendments and Possible Impacts].

Quinones A (1994). La sección 936 [Section 936]. Departamento de Economía, Universidad de Puerto Rico.

Rodrigez CA (2002) Análisis dinámico de la economía de Puerto Rico con un modelo de vectores autorregresivos y cointegración [Dynamic analysis of the economy of Puerto Rico with vector autoregressive model and cointegration]. Revista de Ciencias Sociales (11): 91-110.

Rodrigez CA (2003) Factores que inciden sobre la posibilidad de una desaceleración económica y objetivos de política económica en Puerto Rico [Factors which affect the possibility of an economic slowdown and economic policy objectives in Puerto Rico]. Macroeconomics from EconWPA. Retrieved from http://goo.gl/1OyzJY: 1-28.

Rodrigez CA (2004). A P* model of inflation in Puerto Rico. American Review of Political Economy 2(2): 16-41.

Rodrigez CA (2005) La estabilidad de la demanda de dinero en Puerto Rico [The stability of money demand in Puerto Rico]. Economics and Business Journal 1(2): 39-56.

Rodrigez CA, Toledo W (2007) El efecto de la tasa de los fondos federales de los Estados Unidos sobre la economía de Puerto Rico [The effect of the federal funds rate in the United States on the economy of Puerto Rico]. El Trimestre Económico 74(293): 223-246.

Rodriguez CA (2008) Efectos aceleradores reales de la política monetaria estadounidense sobre una economía pequeña, abierta y totalmente dolarizada: el 
caso de Puerto Rico [Accelerators actual effects of US monetary policy on a small, open and fully dollarized economy: the case of Puerto Rico]. Revista de Ciencias Sociales (16): 30-47.

Ruiz AL, Zalacain F (1996) Algunas sugerencias encaminadas a la reestructuración de nuestra economía en la era post-936 [Some suggestions for the restructuring of our economy in the post-936].

Tobin J (1976) Informe al Gobernador del Comité para el Estudio de las Finanzas de Puerto Rico [Report to the Governor of the Committee for the Study of Finance of Puerto Rico]. Puerto Rico: Universidad de Puerto Rico.

Toledo W (2002) El efecto de la política monetaria estadounidense sobre en la economía de Puerto Rico [The effect of US monetary policy on the economy of Puerto Rico]. Revista de Ciencias Sociales (11): 73-89.

Villamil JJ (1976) El modelo puertorriqueño: los límites del crecimiento independiente [The Puerto Rican model of independent growth limits]. Revista Puertorriqueña de Investigaciones Sociales (1): 3-14. 
